\title{
De hombre a hombre: Carta a Rafael Nabona de Carlos Morales, no escrita desde Jerusalén...*
}

\author{
Carlos Morales** \\ Madrid I Espanha \\ edicioneseltorodebarro@yahoo.es
}

\section{Querido Rafael,}

Me traen noticias los juglares de que no son pocas ni romas las piedras que andan arrojando sobre tu cabeza aquellos viejos amigos tuyos de correrías aberzales con los que sudaste la camisa de tu corazón al servicio de los mitos totalitarios del nacionalismo vasco. He leído, incluso, en los papeles tu demoledora abjuración pública del catecismo independentista de la melancolía gudari, moralmente harto de prestar altavoz a una locura que ha dejado novecientos muertos encima de la mesa.

"La conciencia es implacable - dices - y solo es posible eludir su mandato, cuando el odio y el fanatismo han apagado nuestro último rescoldo de humanidad". No era tu caso. No es que te hayas caído de ningún caballo, es que era sencillamente imposible que una de las estudiosos más lúcidos e implacables de la locura nazi siguiera siendo, por mucho tiempo, el profeta del radicalismo totalitario con que la izquierda aberzale ha manchado de sangre el alma vasca. Era imposible ser dos hombres: con ser el que se es, ya tiene uno bastante.

El paso que has dado, querido Rafael, te sitúa sin ambages frente a las incautas mesnadas del delirio nacionalista. $Y$ lo has hecho en un tiempo de pensamiento débil cuyos alfanjes, cuando se atreven a decir algo, no lo hacen sin habérsela cogido previamente con papel de fumar. Yo, que milité en la Falange Española a los catorce años; que a los dieciséis levanté la mano en saludo fascista ante el viejo cuerpo de un asesino cuarteado, y que gasté mis veinte años en la Liga Comunista Revolucionaria convencido de que era lícito matar por un mundo más justo, sé muy bien cuán grande es el dolor y el desconcierto que se pueden llegar a sentir cuando te das cuenta, por una suerte de extraña iluminación, de hasta que extremos de iniquidad ha podido llevarte la ceguera en que se estaba preso.

\footnotetext{
* Publicado originalmente em Cartas en la noche. Disponivel em< http://cartasenlanoche.blogspot.com/2014/09/de-hombre-hombre-carta-rafaelnabona-de.html>. Acesso em: 10 nov. 2018.

** Escritor e editor de Cartas en la noche: Revista de creación literaria epistolar. 


\section{Arquivo Maaravi}

El espíritu totalitario nos seduce por la sencillez proverbial de los planteamientos con que nos conduce a la violenta exclusión del otro: aquellos que tienen la mala suerte de sufrir su mordedura, acaban convertidos en oscuros animales incapaces de dejar de perseguir su propia sombra. No lo digo yo. Como ya advertía Amin Malouf en su majestuoso estudio sobre las Identidades asesinas, cuanto menos sean los rasgos de identidad con que una sociedad se reconoce a sí misma, más proclive es a dejarse iluminar por la pasión totalitaria; de nada sirve que el sentido común nos advierta de que la catalanidad depende de algo más complejo que una lengua, de que la identidad vasca o alemana no puede reducirse, en modo alguno, a una suerte de espejismo racial, o de que se puede ser perfectamente árabe sin profesar ese odio yihadista a todo el que se mueve y sin buscar la destrucción del Estado y del pueblo de Israel: una vez caídos en el pozo del delirio, sólo media el chasquido de los dedos para que el asesinato del otro se convierta una forma legítima para cambiar el mundo a imagen y semejanza de su estrechura de espíritu.

La historia nos ha dejado claro que quienes han reducido la identidad de los pueblos que decían amar a las solas pinceladas de la nación, o de la clase, o de la raza, o de la religión, o de la lengua, han sido siempre los que han acabado convirtiendo la tierra en un lienzo inundado de cadáveres; y si es verdad que ha habido circunstancias históricas que han hecho para ciertas sociedades más asimilable este mensaje hipnotizador, también lo es que muchos de los individuos que formaban parte de esas sociedades lo arriesgaron todo y decidieron decir $\mathrm{NO}$ a los tambores de quienes, con la excusa de una gran y única idea, terminaron transformando el mundo en un gigantesco apocalipsis. No hay excusas. Está en nuestra mano elegir. Siempre, en cualquier circunstancia, estará en nuestra mano elegir entre la razón y la locura.

Y tú, querido amigo, tras una guerra interior de la que desconozco todo, has elegido ya. Y lo hay hecho en la dirección en que lo hacen los auténticos Hijos del Valor. Te esperan malos tiempos. Hace doce años publiqué una antología de poetas árabes y judíos que, sin dejar de serlo, habían abjurado públicamente de los prejuicios sobre los que se levantaban las imágenes del "buen árabe" y del "buen judío" tan violentamente construidas por los grandes santones de la yihad y del más aberrante y extremo de los sionismos.

Lo hice porque estaba hasta los mismísimos cojones de que estas voces se vieran oscurecidas por quienes, en occidente, solo dan legitimidad y visibilidad a quienes participan o se dejan llevar por ese vocerío identitario de acuerdo con el cual el "otro" no merece otra cosa que la cárcel, la exclusión, el exilio y la muerte. Fue en vano. Apenas hubo una nota de prensa, y poco más. El libro 


\section{Arquivo Maaravi}

murió en silencio porque ponía en evidencia la brutal e inicua ceguera de un Occidente dormido en la molicie e incapaz de llamar a las cosas por su nombre para el que no todas las aventuras totalitarias son igualmente reprobables o merecedoras de igual aceptación. ¿Es que alguna lo es? ¿Es que podrá serlo alguna vez alguna? Todos esos poetas árabes y judíos que, en torno al mismo pan, decidieron compartir la miserable mesa de una editorial de poco cabotaje para decir, para gritar, que era posible aún la coexistencia, lo pasaron realmente mal.

A unos los aislaron en sus propias comunidades; a otros los cuestionaron de mala manera en las tribunas públicas; sobre algunos recayó el estigma insufrible de la tracción; los hubo que tuvieron que cambiar de empleo, y todos se las vieron y se las desearon para no dejar de formar parte de la cultura escuchada. Yo sé lo que se siente cuando alguien te llama traidor, esculpiendo cada una de sus siete letras en la espalda; yo sé lo que se siente cuando una mano anónima deja en el buzón la advertencia de que saben dónde vives y dónde van tus hijos a la escuela. Puedes renunciar al camino, puedes aminorar la marcha que te lleva por él, puedes incluso cobijarte en la guarida donde suele ocultarse el temeroso, pero si aguantas, Rafael, si aguantas, te aseguro que nunca tendrás cicatrices más hermosas que esas en tu carne de hombre. Serán la gran señal de que ¡estás vivo!

Tú, Rafael, ya no tienes más tribu que tú mismo, ni más patria que el sentido común y la cordura. ¿Conoces otra patria mejor?. No tiene sentido ahora dejes sin concluir cosas que nos han ayudado a muchos a pensar un poquito mejor llamando a las cosas por su nombre. Nadie es imprescindible, pero todos somos un poco necesarios, porque nos jugamos mucho. No, querido amigo, no agaches la cabeza, no, porque si algo demuestra lo que has hecho es que Rafael Narbona no ha nacido en modo alguno para ser toro sobrero...

Te dejo aquí un poema de uno del gran poeta galileo Samer Khair, uno de esos Hijos del Valor que decidieron dar el paso hacia los territorios de la coexistencia: "Nadie más que yo - dijo - vivirá mi vida./ Yo señalaré la dirección libremente,/ paso a paso./ No bailaré ni agitaré mis manos/ alrededor del fuego de la tribu,/ como un náufrago agarrado al madero./ Tengo mi propio tiempo aquí,/ en este tiempo./ ¿Por qué ese fuego ha de forjar mi hierro/ y resucitar en mi corazón la vieja espada que otros esgrimieron antes?/ Mis piernas se doblan ahora del cansancio/ porque siguen un camino diferente al vuestro./ Manteneos lejos de mi ruta/ para que mis manos puedan caminar/ a solas por ella./ Porque nadie sino yo, os lo aseguro, vivirá mi vida."

¿Te recuerda algo? Eso se acabó, Rafael: lame tus cicatrices, pero hazlo con la conciencia de que tú ya no eres "un náufrago agarrado al madero" de la locura. 


\section{Arquivo Maaravi}

7 Revista Digital de Estudos Judaicos da UFMG

Por eso te dejo este poema de mi amigo Samer: no tengo otra manera de que el hombre que yo soy abrace con alegría a al hombre verdadero que tú eres.

Tuyo

Carlos.

Recebido em: 10/06/2018.

Aprovado em: 10/08/2018. 